\title{
Efficacy and safety of procedural sedation with propofol in a country with a young emergency medicine training program
}

\author{
Maybritt I Kuypers ${ }^{1 *}$, Francis Mencl ${ }^{2}$, Matthijs F Verhagen ${ }^{3}$, Maarten F Kok ${ }^{4}$, Lea M Dijksman ${ }^{3}$, Maarten P Simons ${ }^{3}$ \\ From Danish Society for Emergency Medicine: Research Symposium 2010 \\ Roskilde, Denmark. 20-21 May 2010
}

\section{Background}

In The Netherlands emergency medicine is a relatively new specialty. The aim of this study was to evaluate the effectiveness and safety of procedural sedation with propofol by newly trained Dutch emergency physicians.

\section{Methods}

A prospective observational cohort study of emergency department patients undergoing procedural sedation at two teaching hospitals. Primary outcomes were serious adverse events, sedation events and efficacy. A standardized protocol and data collection form was used at both sites.

\section{Results}

386 patients were enrolled over 18 months. The median age was 57 (IQR $38-70$ ) years, $55 \%$ were male. All had ASA class score $\leq 3$. Indications for procedural sedation were reduction of dislocations (52\%), electro-cardioversion (32\%), fracture reduction (9\%) and abscess/wound treatment (6\%). The median propofol dose was $1.0 \mathrm{mg} / \mathrm{kg}$ (0.70-1.5) and $44 \%$ also received fentanyl; median dose 1 $\mathrm{mcg} / \mathrm{kg}$ (0.6-1.3). Most had a Ramsay sedation score of 4 or $5(54 \%)$. The procedural success rate was $99.5 \%$. No serious adverse events were reported. Sedation events included; hypoventilation (11\%), desaturation (5\%), hypotension (3\%) and bradycardia (1\%), all of which resolved with simple supportive interventions. One patient vomited without aspirating. Increased age $(\mathrm{p}=0.001)$ and high Ramsey score $(>3)(\mathrm{p}=0.024)$ were the only significant predictors of events. Gender, weight, total dose of propofol, use of fentanyl and type of procedure were not independent risk factors for any event.

\footnotetext{
* Correspondence: m.kuypers@westfriesgasthuis.nl

${ }^{1}$ Wesfriesgasthuis, Hoorn, The Netherlands

Full list of author information is available at the end of the article
}

\section{Conclusion}

Procedural sedation with propofol can be performed safely and effectively by newly trained Dutch emergency physicians. Increased age and high Ramsay scores were the only risk factor for sedation events. All events were minor and responded to simple interventions. Possibly this study can aid the introduction of procedural sedation with propofol by emergency physicians in other countries where emergency medicine is a new and upcoming specialty.

\section{Author details}

${ }^{1}$ Wesfriesgasthuis, Hoorn, The Netherlands. 'Summa Health Systems, Akron, Ohio, USA. ${ }^{3}$ Onze Lieve Vrouwe Gasthuis, Amsterdam, The Netherlands. ${ }^{4}$ Rode Kruis Ziekenhuis, Beverwijk, The Netherlands.

Published: 17 September 2010

doi:10.1186/1757-7241-18-S1-O1

Cite this article as: Kuypers et al:: Efficacy and safety of procedural sedation with propofol in a country with a young emergency medicine training program. Scandinavian Journal of Trauma, Resuscitation and Emergency Medicine 2010 18(Suppl 1):O1.

Submit your next manuscript to BioMed Central and take full advantage of:

- Convenient online submission

- Thorough peer review

- No space constraints or color figure charges

- Immediate publication on acceptance

- Inclusion in PubMed, CAS, Scopus and Google Scholar

- Research which is freely available for redistribution

Submit your manuscript at

www.biomedcentral.com/submit

Ciomed Central 